\title{
Agricultural abandonment and re-cultivation during and after the Chechen Wars in the northern Caucasus
}

Yin, He; Butsic, Van; Buchner, Johanna; Kuemmerle, Tobias; Prishchepov, Alexander V.;

Baumann, Matthias; Bragina, Eugenia V.; Sayadyan, Hovik; Radeloff, Volker C.

Published in:

Global Environmental Change

DOI:

10.1016/j.gloenvcha.2019.01.005

Publication date:

2019

Document version

Publisher's PDF, also known as Version of record

Document license:

Unspecified

Citation for published version (APA):

Yin, H., Butsic, V., Buchner, J., Kuemmerle, T., Prishchepov, A. V., Baumann, M., Bragina, E. V., Sayadyan, H., \& Radeloff, V. C. (2019). Agricultural abandonment and re-cultivation during and after the Chechen Wars in the northern Caucasus. Global Environmental Change, 55, 149-159.

https://doi.org/10.1016/j.gloenvcha.2019.01.005 


\title{
$\mathrm{H} \quad \mathrm{i} \quad \mathrm{C} \quad \mathrm{N}$ Households in Conflict Network
}

The Institute of Development Studies - at the University of Sussex - Falmer - Brighton - BN1 9RE

www.hicn.org

\section{Agricultural abandonment and re- cultivation during and after the Chechen Wars in the northern Caucasus}

\author{
He Yin ${ }^{\mathrm{a}}$, Van Butsic ${ }^{\mathrm{b}}$, Johanna Buchner, Tobias Kuemmerle, ${ }^{\mathrm{c}, \mathrm{d}}$, Alexander V. \\ Prishchepov $^{\mathrm{e}, \mathrm{f}}$, Matthias Baumann ${ }^{\mathrm{c}}$, Eugenia V. Bragina ${ }^{\mathrm{g}}$, Hovik Sayadyan ${ }^{\mathrm{h}}$ and \\ Volker C. Radeloff ${ }^{a}$ \\ HiCN Working Paper 294
}

\begin{abstract}
March 2019
Abstract: Armed conflicts are globally widespread and can strongly influence societies and the environment. However, where and how armed conflicts affect agricultural land-use is not well-understood. The Caucasus is a multi-ethnic region that experienced several conflicts shortly after the collapse of the Soviet Union, most notably the two Chechen Wars, raising the question how agricultural lands were changed. Here, we investigated how the distance to conflicts and conflict intensity, measured as the number of conflicts and the number of casualties, affected agricultural land abandonment and subsequent re-cultivation, by combining social, environmental and economic variables with remotely-sensed maps of agricultural change. We applied logistic and panel regression analyses for both the First Chechen War (1994-1996) and the Second Chechen War (1999-2009) and interacted conflict distance with conflict intensity measures. We found that agricultural lands closer to conflicts were more likely to be abandoned and less likely to be re-cultivated, with stronger effects for the First Chechen War. Conflict intensity was positively correlated with agricultural land abandonment, but the effects differed based on distance to conflicts and the intensity measure. We found little re-cultivation after the wars, despite abundant subsidies, indicating the potentially long-lasting effects of armed conflicts on land-use. Overall, we found a clear relationship between the Chechen Wars and agricultural land abandonment and re-cultivation, illustrating the strong effects of armed conflicts on agriculture.
\end{abstract}

Keywords: Agricultural land abandonment, armed conflict, ethnic conflict, land-use change, re-cultivation, warfare.

\footnotetext{
${ }^{a}$ Corresponding Author: He Yin, E-mail: hyin39@wisc.edu, Phone: +1 6082659219

SILVIS Lab, Department of Forest and Wildlife Ecology, University of Wisconsin-Madison, 1630 Linden Drive, Madison, WI 53706, USA

${ }^{\mathrm{b}}$ Department of Environmental Science, Policy, and Management, University of California Berkeley, 101 Sproul Hall, Berkeley, CA 94704, USA

${ }^{\mathrm{c}}$ Geography Department, Humboldt-Universität zu Berlin, Unter den Linden 6, 10099 Berlin, Germany

${ }^{d}$ IRI THESys, Humboldt-Universität zu Berlin, Unter den Linden 6, 10099 Berlin, Germany

${ }^{\mathrm{e}}$ Department of Geosciences and Natural Resource Management (IGN), University of Copenhagen, Øster Voldgade 10, DK-1350 København K, Denmark

${ }^{\mathrm{f}}$ Institute of Environmental Sciences, Kazan Federal University, Kazan, Tovarisheskaya str.5, 420097, Kazan, Russia

${ }^{\mathrm{g}}$ Wildlife Conservation Society, 2300, Southern Boulevard, Bronx Zoo, NY 10460-1099S, USA

${ }^{\mathrm{h}}$ Department of Physical Geography, Yerevan State University, Yerevan, Armenia
} 


\section{Introduction}

Armed conflicts often have tragic humanitarian consequences (Gates et al., 2012; Li and Wen, 2005) and can have far-reaching and long-lasting environmental effects (Dupuy et al., 2017; Nita et al., 2018). Military operations often target the environment (Austin and Bruch, 2000), and entail adverse environmental outcomes such as defoliation, water contamination and air pollution. For instance, the Vietnam War had devastating environmental effects due to the US' defoliation campaign (Westing, 1976). Similarly, the Gulf War (1990-1991) led to the destruction of more than 700 Kuwaiti oil fields and refineries, creating major atmospheric, marine, and coastal contamination (Gerges, 1993; Price et al., 1994). Conversely, armed conflicts can also benefit the environment. Habitat can be protected when people avoid areas of violence, exemplified by flourishing wildlife in the Demilitarized Zone between North and South Korea (Gaynor et al., 2016; Kim, 1997; Martin and Szuter, 1999). Assessing the diverse environmental outcomes of armed conflicts is therefore important.

One open question is how armed conflicts affect land use, particularly agriculture in the form of agricultural land abandonment or shifts in agricultural production during and after the conflicts (Baumann and Kuemmerle, 2016; Urdal, 2005). Several causal mechanisms through which conflicts affect agricultural land-use decisions are plausible. Armed conflicts can affect agricultural land-use directly through the destruction of agricultural fields and environmental contamination. For example, deliberate cropland destructions to destabilize the opposing parties were part of conflicts such as in Ethiopia (Hendrie, 1994), Guatemala (Tomuschat et al., 1999), and Rwanda (Baechler, 1996) even though the Article 54 of the 1977 Protocol to the 1949 Geneva Conventions prohibits to "attack, destroy, remove or render useless objects indispensable to the survival of the civilian population, such as foodstuffs, agricultural areas for the production of 
foodstuffs, crops, livestock, drinking water installations and supplies and irrigation works".

Furthermore, environmental contamination, such as soil and water pollution, can reduce land productivity and affect land-use directly (Formoli, 1995). Indeed, a substantial portion of the available agricultural land in many countries cannot be used as a result of conflicts (Biswas, 2001; Trevelyan et al., 2002).

In addition to the direct effects of armed conflicts on land use, they can also affect institutions, infrastructure, technology, the economy or the population, and those changes can be indirect causes of agricultural land-use change (Keen, 2000; Serneels and Verpoorten, 2015). Institutions' capacity to act is often limited during armed conflicts. Chaos and instability can damage the agricultural sector through a loss of market access and a shortage of agricultural inputs (e.g. seeds, fertilizer). As a result, farming can be less productive and more costly (ICRC, 2007). Alternatively, armed conflicts can stimulate agriculture when agricultural revenues fund war parties. For instance, the Islamic State in Syria and Iraq (ISIS) forced landowners to continue agricultural production because agriculture was an important source of income (Jaafar and Woertz, 2016). Military operations destroying transportation infrastructure can reduce access to markets, which disrupts agriculture (FAO, 2000; Unruh and Shalaby, 2012). Armed conflicts also limit the incentives in investments in technologies, making agricultural production primitive and costly (Brück, 2001). Demographic changes due to, for example, ethnic cleansing and soldier recruitment during the armed conflicts can create labor shortages that constrain agricultural activities (Suthakar and Bui, 2008). Internally displaced persons (IDPs), however, may increase agricultural activities at their destination locations while reducing them at their origins (Gbanie et al., 2018). For example, the 1994 genocide in Rwanda displaced three out of four farmers, and hence agricultural activity (FAO, 2000). 
Despite many plausible mechanisms for how armed conflicts may lead to agricultural land-use change, empirical evidence for such links is not conclusive (Baumann and Kuemmerle, 2016). Agricultural land abandonment was prevalent in the conflict areas of Bosnia (Witmer, 2008), Colombia (Sánchez-Cuervo and Aide, 2013), Kosovo (Douarin et al., 2012), Lebanon (Darwish et al., 2009), Nicaragua (Stevens et al., 2011), and Sri Lanka (Suthakar and Bui, 2008), while both agriculture abandonment and expansion occurred in the Caucasus (Baumann et al., 2015), Iraq (Jaafar and Woertz, 2016), Syria (Eklund et al., 2017), Sierra Leone (Gbanie et al., 2018), and Sudan (Alix-Garcia et al., 2013). Similarly, post-conflict agricultural land-use change can be complex. For instance, agricultural land abandoned during a conflict may be recultivated after its end (Wilson and Wilson, 2013), but it may also be permanent if the armed conflict affected both land tenure and institutions and introduced new rules of land-use and management (United Nations, 2012).

Given equally plausible potential outcomes, predicting the effect of armed conflicts on agricultural land-use is difficult. One reason is that armed conflicts can have different effects on agricultural land-use depending on the intensity of the conflict (Biswas, 2001; Ordway, 2015), and the effect of armed conflicts on agriculture can depend on the distance to the conflicts. Areas closer to the conflict sites have typically higher land-use change rates, while regions afar are less affected (Baumann et al., 2015; Witmer, 2008). It is also crucial to control for potential other drivers such as environmental conditions as well as to account for possible unobserved factors (Butsic et al., 2015; Gorsevski et al., 2013; Sánchez-Cuervo and Aide, 2013). Statistical techniques to do so are increasingly available, such as propensity score matching (Alix-Garcia et al., 2012), structural equation models (Grinfelde and Mathijs, 2004), panel regressions (Allison, 
2009) or Bayesian networks (Frayer et al., 2014), and can assist in establishing causality when combined with qualitative approaches.

The northern Caucasus is an ideal region to explore the land-use outcomes of armed conflicts. After the collapse of the Soviet Union in 1991, several armed conflicts took place in the region, among which the two Chechen Wars (First 1994-1996, Second 1999-2009) were some of the most violent confrontations in Europe since World War II, with 80,000-250,000 civilian casualties, and more than 800,000 internally displaced persons (IDP) (IDMC, 2018; Russell, 2005). Three years after Chechnya declared independence, Russia launched a 21-month campaign, the First Chechen War, which ended in 1996 when Russian forces withdrew and Chechnya gained de facto independence, albeit with rampant corruption, revolts, and crime (Zürcher, 2007). Furthermore, after Chechen rebels invaded Dagestan to establish a fundamentalist Islamic state, Russia responded with a new campaign in 1999, the Second Chechen War, which later transformed into a 'war on terror' against Islamic fundamentalist (Zabyelina, 2013). In 2009, the pro-Moscow Chechen government announced the end of the counter-terrorism operation, and while stability was largely reinstalled, clashes with militants and insurgencies remained common throughout the northern Caucasus (Holland et al., 2018; O'Loughlin et al., 2011; O'Loughlin and Witmer, 2012). Though the social, political and economic consequences of the Chechen Wars have been evaluated, how agricultural land-use were altered during and after the conflicts remained unknown (Vendina et al., 2007; Williams, 2001; Witmer and O'Loughlin, 2011).

Advances in land-use mapping and armed conflict data now provide an opportunity to investigate the complex interactions between agriculture and armed conflicts in this region. Spatially explicit information on the timing of agricultural land-use change, for instance, is 
necessary to quantitatively assess the consequences of the armed conflicts on agriculture landuse. Recently, dense time series of satellite images allow us to analyze land-use change at high temporal and spatial resolution, e.g., with 30-m Landsat imagery in the northern Caucasus (Yin et al. 2018). Using this dataset, along with the database on conflicts and unrests developed by Uppsala Conflict Data Program (UCDP, Sundberg and Melander, 2013), our goal was to assess the relationships of armed conflicts during and after the Chechen wars with agricultural land abandonment and re-cultivation. Specifically, we ask the following questions:

1) How much agricultural land was abandoned and re-cultivated in the conflict area?

2) Was agricultural land abandonment more likely in areas closer to conflicts?

3) Was agricultural land abandonment more likely in areas with higher conflict intensity?

\section{Study area and methods}

\subsection{Northern Caucasus}

Our study area covered the North Caucasian Federal District of Russia, including parts of the Chechen Republic, the Republic of Ingushetia, the Republic of North Ossetia-Alania, the Republic of Kabardino-Balkaria and Stavropolskij Kraj (Stavropol). The study area is divided into the southern highland and the northern lowland. The southern highland contains the foothills of the Greater Caucasus Mountains, and the northern lowland consists of the Terek River basin (Figure 1). The climate is continental with average temperature changing from $-4{ }^{\circ} \mathrm{C}$ in January to $24^{\circ} \mathrm{C}$ in July, and the annual precipitation ranges from $500 \mathrm{~mm}$ on plains to 1000 $\mathrm{mm}$ in the foothills. The common soils in the study region are very fertile chernozem and the less common chestnut soils (Afonin et al., 2008). 
Environmental conditions make the northern Caucasus well-suited for crop production and resulted in the highest grain yield of Russia in the Soviet times (FAO, 2009; Ioffe et al., 2004). However, since the 1990s, the agricultural sector in the northern Caucasus went through a drastic transition as Russia transformed its economy from central-command to marketoriented. After the collapse of the Soviet Union, the large-scale state (sovkhoz) and collective (kolkhoz) farms were gradually privatized in Russia (Uzun et al., 2014). The Land Code of the Russian Federation gives regions the right to decide the date and type of land reform. The Stavropol region underwent privatization, but a full-fledged land market and complete private land ownership was not established (Kolosov et al., 2017). Especially the adjustment of property and field boundaries was both technically challenging and resisted by ethnic, administrative, and business elites. As a result, the field boundaries of former collective farms were kept, and relatively few modern agro-complexes specialized in grain and flour production emerged. In contrast, Chechnya, Dagestan, Ingushetia, Kabardino-Balkaria and North Ossetia did not legislate any formal land privatization, though in practice lands often belong to elites (Caucasian Knot, 2013), and de facto privatization by farmers occurred in some places (Gunya, 2017). In Chechnya, for example, the state regulates access to land while district municipalities regulate land in other republics. As a result, legislative contradictions concerning the status and use of agricultural lands are prevalent in the northern Caucasus (Koehler et al., 2017). In terms of agricultural land use, abandonment has been widespread throughout Russia since the early 1990s due to the termination of large subsidies to agriculture (Ioffe and Nefedova, 2000). Armed conflicts may have exacerbated this decline in agriculture in the northern Caucasus. For example, a household survey conducted in Chechnya and Ingushetia before and after the conflicts found a major decline in agricultural output and productivity (OCHA, 2005). 


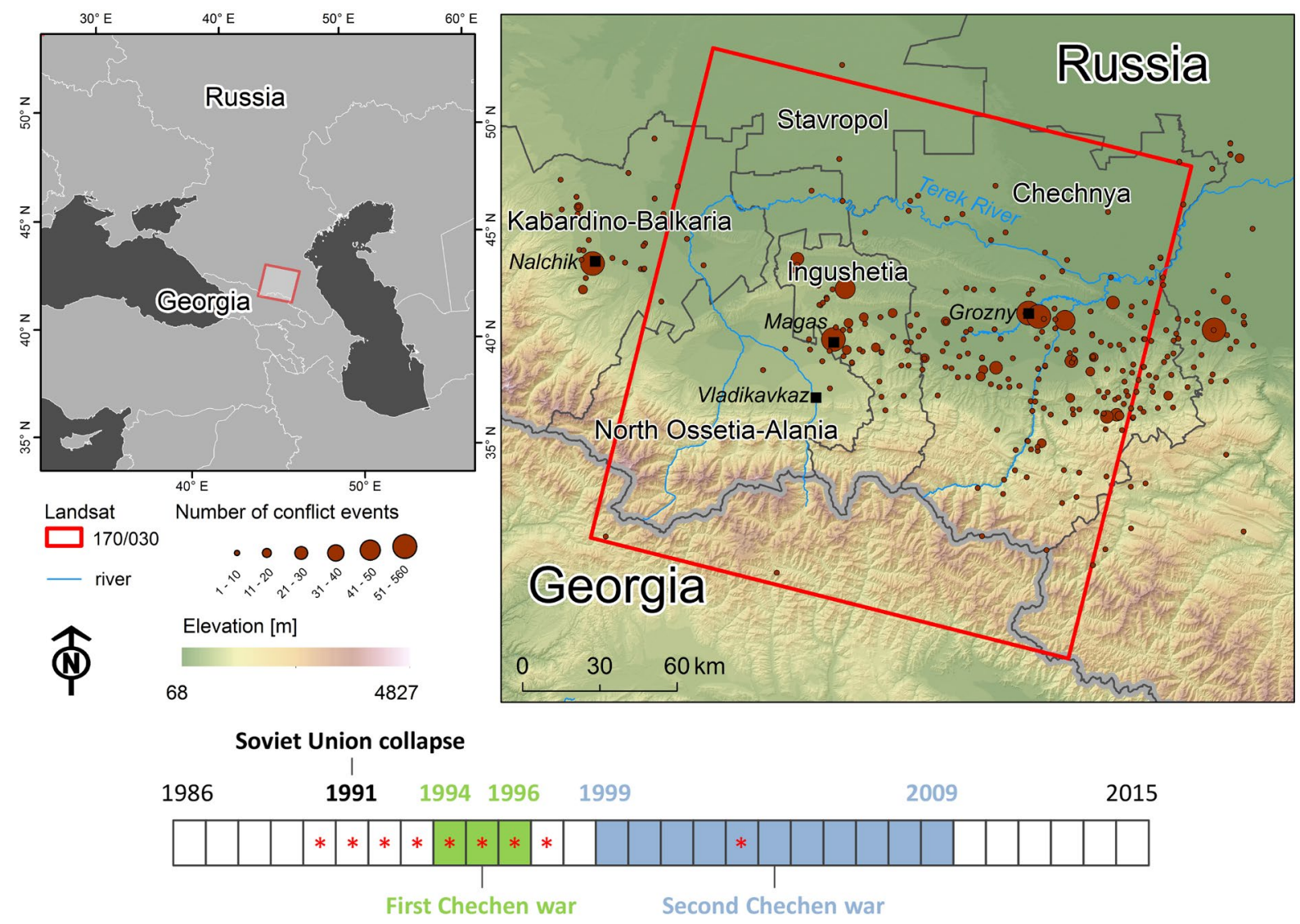

Figure 1: Conflict events in the northern Caucasus from 1989 to 2011 according to the Uppsala Conflict Data Program (Sundberg and Melander, 2013). A conflict event is defined as "an incident where armed force was used by an organized actor against another organized actor, or against civilians, resulting in at least one direct death at a specific location and a specific date" (Sundberg and Melander, 2013). The figure in the bottom shows the timeline of the collapse of the Soviet Union, and the Chechen Wars. The red asterisk indicates a lack of Landsat observations in the dataset of Yin et al. (2018).

\subsection{Remotely sensed land-use change}

To understand the relationships between the Chechen Wars and agricultural land-use change, we analyzed spatial and temporal variations in agricultural land abandonment and recultivation relative to the locations of armed conflicts, and to spatial variation in key biophysical and accessibility factors. 
To estimate agricultural land-use change between 1986 and 2011, we analyzed a map of stable (active) agriculture, agricultural abandonment, re-cultivation of abandoned lands, and fallow land from Landsat imagery for one Landsat footprint path 170 and row 030 that we classified previously (Yin et al., 2018). We selected this Landsat footprint because it covers most of Chechnya and Ingushetia and it included the vast majority $(83 \%)$ of conflict events in the northern Caucasus according to the Uppsala Conflict Data Program Georeferenced Event Dataset (section 2.3).

In that map, agricultural land abandonment was defined as agricultural land that had not been used for at least five years (FAO, 2016) and re-cultivation as abandoned agricultural land that was re-used for more than four years. These maps were generated based on a total of 301 Landsat images obtained from the United States Geological Survey (USGS, 236 images) and the European Space Agency (ESA, 65 images). We estimated annual active agricultural land probability using a machine learning approach and recorded the timing of agricultural land abandonment and re-cultivation based on temporal segmentation. Because of an eight-year data Landsat gap from 1990 to 1997, we aggregated agricultural land abandonment between 1989 and 1998 into one class (Figure 1). Agricultural land abandonment classes had producer's and user's accuracies of $69 \%$ and $66 \%$, while re-cultivation had producer's and user's accuracies of $71 \%$ and $57 \%$, respectively (Yin et al., 2018).

We calculated agricultural land abandonment and re-cultivation rates at certain distances to the nearest conflict event (section 2.3). Abandonment rates were calculated as the proportion of abandoned pixels relative to all agricultural land at each distance interval (i.e., < $1 \mathrm{~km}, 1-3 \mathrm{~km}, 3-6 \mathrm{~km}, 6-9 \mathrm{~km}$ and $>9 \mathrm{~km})$. Re-cultivation rates were calculated as the percentages of abandoned lands that were re-cultivated. 


\subsection{Conflict events and other variables}

We selected the Uppsala Conflict Data Program (UCDP) Georeferenced Event Dataset (GED) to model the influence of the conflicts on agricultural land-use (Sundberg and Melander, 2013). While there are other conflict datasets (e.g. Holland et al., 2018), we selected the GED because of its longer time coverage (starting in 1989). The UCDP defines a conflict event as "an incident where armed force was used by an organized actor against another organized actor, or against civilians, resulting in at least one direct death at a specific location and a specific date" (Sundberg and Melander, 2013). The GED provides detailed spatial and temporal information of individual conflict events across the globe. Different aspects of a conflict event include the best estimate of the number of dead civilians (civilian casualties) and total casualties. We extracted all events in our study area and the surrounding regions from 1989 to 2011 (Figure 1). We used only records with high-confidence geolocation precision, which was the case for $83 \%$ of them. For sites that experienced multiple conflict events within one year, we summed the number of conflict events and the number of casualties, including civilian casualties and total casualties. In total there were 2,329 recorded conflict events in our study area and study period.

Table 1 List of variables used for quantifying the influence of the Chechen Wars on agricultural land-use change.

\begin{tabular}{|c|c|c|c|c|c|}
\hline & Category & Variable description & Period & Unit & Source \\
\hline \multirow{2}{*}{$\begin{array}{l}\text { Response } \\
\text { variables }\end{array}$} & \multirow{2}{*}{$\begin{array}{l}\text { Agricultural } \\
\text { land-use } \\
\text { change }\end{array}$} & $\begin{array}{l}\text { Agricultural land } \\
\text { abandonment }\end{array}$ & $\begin{array}{l}1986-1989, \\
1998-2011\end{array}$ & $\begin{array}{c}\text { 1: abandonment, } 0 \text { : } \\
\text { no abandonment }\end{array}$ & Yin et al. (2018) \\
\hline & & $\begin{array}{l}\text { Abandoned agricultural } \\
\text { re-cultivation }\end{array}$ & $1999-2011$ & $\begin{array}{l}\text { 1: re-cultivation, } 0 \text { : } \\
\text { no re-cultivation }\end{array}$ & Yin et al. (2018) \\
\hline \multirow{4}{*}{$\begin{array}{l}\text { Conflict co- } \\
\text { variables }\end{array}$} & Conflict & The distance to the nearest & $1989-2011$ & $\mathrm{~km}$ & Sundberg and \\
\hline & distance & conflict event & & & Melander (2013) \\
\hline & Conflict & Number of conflict events & $1989-2011$ & number & Sundberg and \\
\hline & intensity & & & & Melander (2013) \\
\hline
\end{tabular}




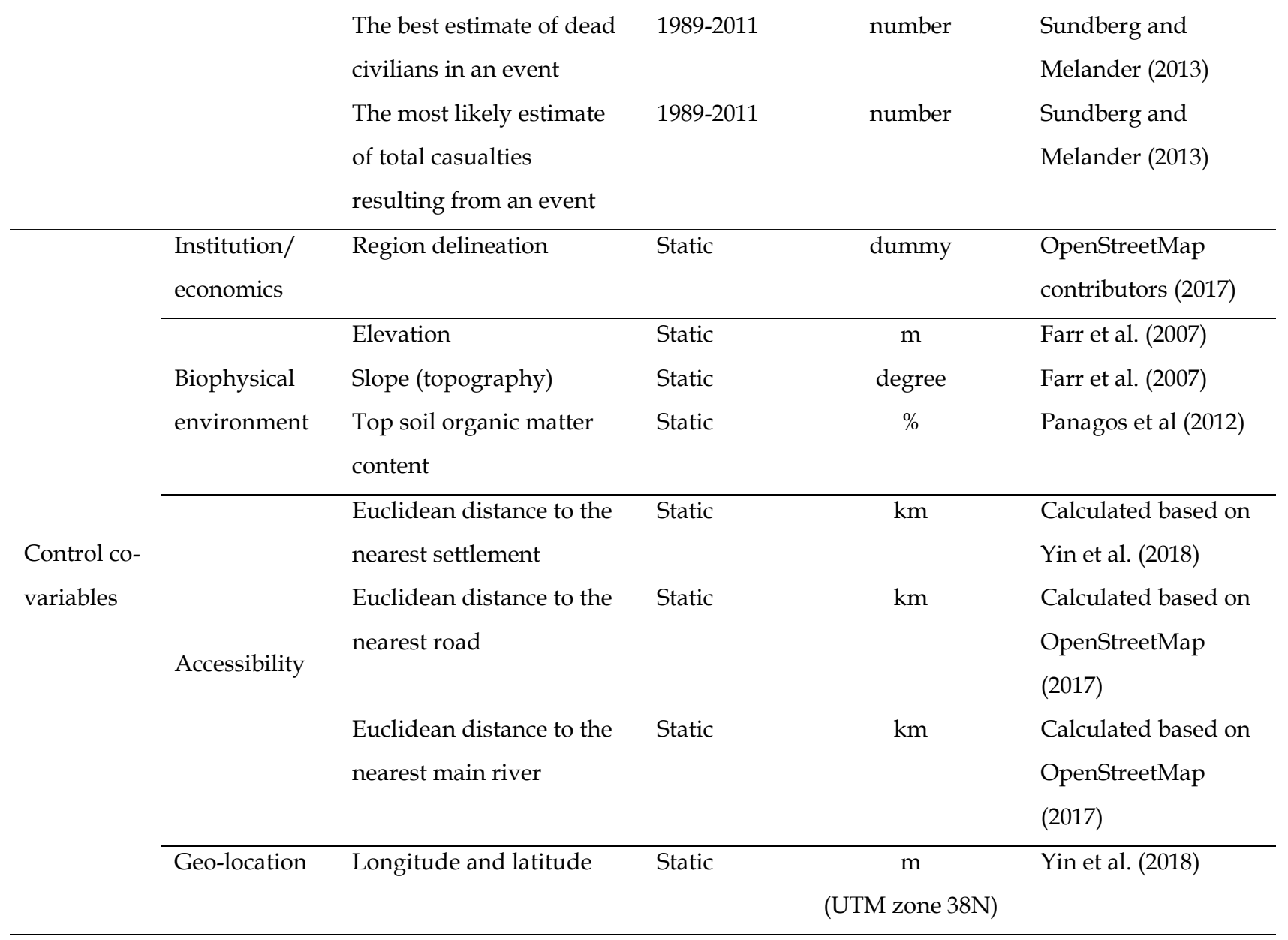

Agricultural land-use change can be caused by many factors other than conflicts (Geist and Lambin, 2002; Meyfroidt et al., 2016; Osawa et al., 2016) that need to be accounted for when estimating the effects of armed conflicts. We included three groups of control co-variables in our models: institutional and economic factors, environmental factors, and accessibility factors (Table 1). For institutional and economic factors, we added a dummy variable "region" in the model to control for the potential influence of regional governmental management and policies across five republics/Kraj in the northern Caucasus. Environmental variables, such as elevation, topographic slope, and soil organic matter, determine yields and are closely linked to agricultural land abandonment in European Russia (Prishchepov et al., 2013). The soil organic matter was compiled from the European Soil Database (Panagos et al., 2012), which divided our 
study area into 17 zones. Regarding accessibility, we calculated the distance of pixels to agricultural land, to the nearest settlement, road, and river. Settlements were identified manually based on Yin et al. (2018) with the aid of the OpenStreetMap

(www.openstreetmap.org). We also added longitude and latitude to each sample in the models to account for spatial autocorrelation. We did not include demographic data in our models because the population data in the northern Caucasus was unfortunately incomplete and unreliable.

\subsection{Model design}

We used a series of statistical techniques to quantify the effects of the Chechen Wars on agricultural land change including logistic, fixed-effects, and random-effects regression models (Table 2). We modeled land-use change for the First and the Second Chechen War separately, because of differences in data structure. For the First Chechen War, we only had one agricultural land abandonment class (land abandonment 1989-1998) due to a lack of Landsat data from 1990 to 1997 (Figure 1), while for the Second Chechen War annual data on agricultural land abandonment and re-cultivation was available, making it well-suited for panel analysis.

Satellite image classifications contain millions of pixels and hence observations, but most of them are spatially autocorrelated. To increase computational speed and reduce spatial autocorrelation, we randomly sampled 5\% of all pixels in the map and included coordinates of all the pixels in the models (Section 2.3). In all, 29,968 pixels of agricultural land abandonment and 294,037 pixels of non-abandoned agricultural land from 1989 to 1998 were selected for modeling. About $8.4 \%$ and $8.0 \%$ of the selected pixels showed agricultural land abandonment during the First and the Second Chechen War, respectively. About $15.8 \%$ of the selected abandonment pixels were re-cultivated later. To assess how distance to conflict affected the 
probability of agricultural land abandonment, we calculated the distance of each pixel to the closest conflict site. To understand the influence of conflict intensity, we analyzed the number of conflict events, civilian casualties, and total casualties (Strandow et al., 2014; Vité, 2009). We assigned the number of conflicts, civilian casualties, and total casualties from the closest conflict site to a given pixel, and calculated elevation, slope, and soil top organic matter for each pixel based on the 30-m SRTM DEM and 1-km European Soil Database. We also calculated the distances of each pixel to the nearest paved road and to the nearest river using the OpenStreetMap (www.openstreetmap.org) data. We performed log transformation on the control co-variables and conflict intensity measurements.

We fitted three logistic regression models to explain agricultural land abandonment between 1989 and 1998 (Eq. 1). Each of the three models included one of the conflict intensity measurements, i.e., either the number of conflicts, the number of civilian casualties, or the number of total casualties, as an explanatory variable as well as additional control co-variables (Table 2). In each regression model, we interacted the conflict intensity variable with the distance to the conflicts. To better understand the local effect of the conflicts on land abandonment we plotted the marginal effects of conflict number, civilian casualties, and total casualties for multiple conflict distance levels. The marginal effects illustrate the changes in predicted probabilities of the dependent variable (outcome) when a specific covariate changes while all other co-variables are assumed to be held constant. To compare the marginal effects of the two Chechen Wars, we standardized the marginal effects of the Second Chechen War by integrating annual predicted probabilities over the whole observation period. Thus, the marginal effects of the First Chechen War represented the likelihood of agricultural land abandonment over the period 1989-1998 while the marginal effects of the Second Chechen War showed the likelihood of change during 1999-2011. 


$$
y_{i}=B_{1} * C_{i}+B_{2} * D_{i}+B_{3} * C_{i} * D_{i}+B_{4-12} * E_{i}+\varepsilon_{i}
$$

where $y_{i}$ is agricultural land abandonment (1) or not (0) for pixel $i$ during 1989-1998, $C$ is the log of the conflict intensity measurement (i.e. conflict number, casualties) for pixel $i$ during 1989$1998, D$ is the log of the distance to the nearest conflict event for pixel $i$ during $1989-1998, E_{i}$ is a vector of covariates including the log of elevation, slope, soil organic matter, distances to the nearest settlement, river and road, the regional dummy variable, the longitude and latitude for pixel $i$, the $B$ s are the coefficients to be estimated and $\varepsilon$ represents an error term.

Table 2 List of models used in this study. Response variables (i.e., agricultural abandonment, recultivation) are highlighted in green color while selected control co-variables and independent variables are highlighted in grey color for each model.

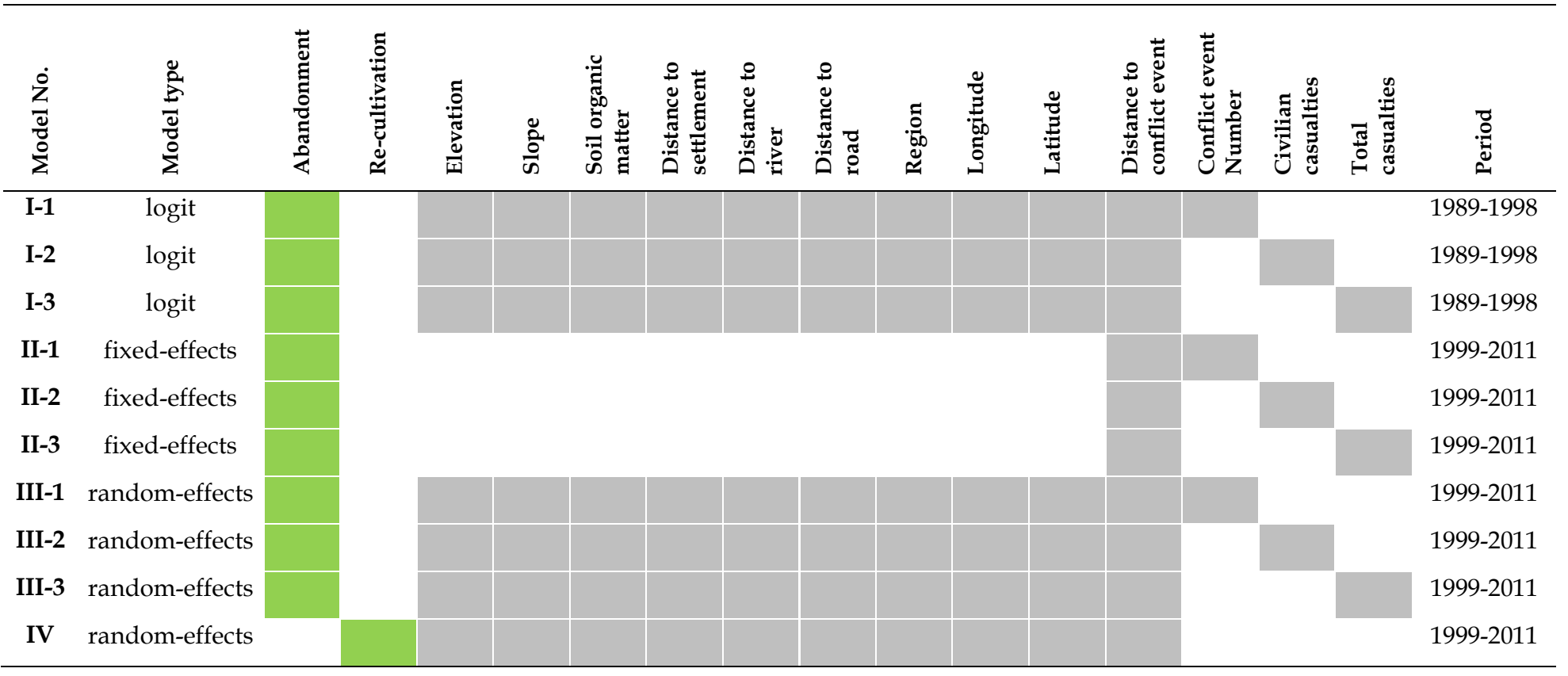

Second, we parameterized panel regression models (i.e., models based on datasets that have repeated observations), both fixed-effects and random-effects models, to investigate the effect of the Second Chechen War on agricultural land abandonment, a period for which we had 
annual data of agricultural land-use change. We used the definitions most common in econometric, where fixed- and random-effect models are defined by their error structure. The fixed-effects regression model has advantages because it controls for all stable, unobservable variables, and it has been widely used in land use science and the social sciences (Allison, 2009; Arima et al., 2011; Seto and Kaufmann, 2003). The random-effects model, however, has the advantage of providing coefficients for time-invariant variables, which cannot be estimated in fixed-effects models. For the panel models, we labeled each pixel in each year as either abandoned or non-abandoned. For instance, if a pixel was abandoned in 2006, it was labeled as "abandonment" in 2006 and "non-abandoned" from 1999 to 2005. Therefore, our models can be interpreted as linear probability models, which have been effectively used for modeling landuse change elsewhere (Butsic et al., 2017). Again, we calculated the distance of each pixel to the nearest conflict event, and the number of conflict events, civilian casualties, and total casualties. We then ran three fixed-effects models interacting the distance to conflict event with one of the conflict intensity measures and calculated the marginal effects of each model (Eq. 2 and Eq. 3).

$$
y_{i t}=B_{1} * C_{i t}+B_{2} * D_{i t}+B_{3} * C_{i t} * D_{i t}+\varepsilon_{i t}
$$

where $y_{i t}$ is agricultural land abandonment (1) or not (0) for pixel $i$ at year $t, C$ is the $\log$ of the conflict intensity measurement (i.e. conflict number, casualties) for pixel $i$ at year $t, D$ is the $\log$ of the distance to the nearest conflict for pixel $i$ at year $t$, the $B$ s are the coefficients to be estimated, and $\varepsilon$ represents random variation.

$$
y_{i t}=B_{1} * C_{i t}+B_{2} * D_{i t}+B_{3} * C_{i t} * D_{i t}+B_{4-12} * E_{i}+\varepsilon_{i t}
$$

Third, we followed the same approach to investigate the effect of armed conflicts on recultivation (Eq. 4). Because re-cultivation was much less common, we fitted models using only distance to conflicts as an independent variable to predict re-cultivation.

$$
z_{i t}=B_{1} * D_{i t}+B_{2-10} * E_{i}+\varepsilon_{i t}
$$


where $z_{i t}$ is agricultural re-cultivation (1) or not (0) for pixel $i$ at year $t$.

\section{Results}

\subsection{Spatio-temporal pattern of the armed conflicts}

During the First Chechen War (1994-1996), most of the conflicts occurred in Chechnya, which accounted for $96 \%$ of the conflict events in our study area. The same holds true for the early stage of the Second Chechen War (1999-2003) when conflict events were also concentrated in Chechnya. However, in the later stage of the Second Chechen War (2004-2009), conflicts spread to the surrounding regions especially Ingushetia. In the post-Chechen War era the number of conflict events decreased but were more widely spread (Figure 2).

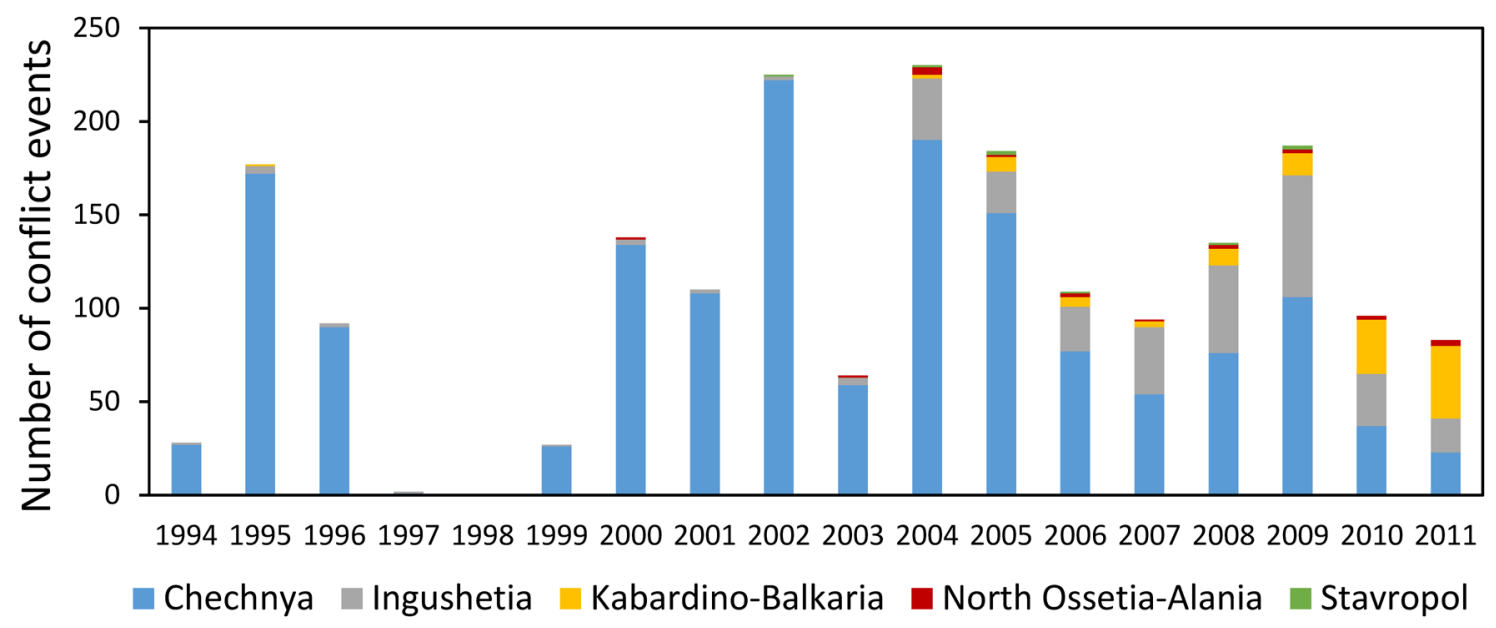

Figure 2 The number of conflict events in the study area.

\subsection{Land abandonment and re-cultivation}

We found more agricultural land abandonment in areas that were closer to armed conflicts (Figure 3). About $44.9 \%$ of agricultural land within $1 \mathrm{~km}$ from conflicts was 
abandoned. Agricultural land abandonment rates gradually decreased with distance to conflicts. For example, $>9 \mathrm{~km}$ afar from a conflict, only $5.9 \%$ of agricultural land was abandoned. We found higher re-cultivation of abandoned agricultural land that was farther from conflicts. Nearly $27.9 \%$ of abandoned land was re-cultivated $>9 \mathrm{~km}$ afar from conflicts, compared to $5.9 \%$ within $1 \mathrm{~km}$.

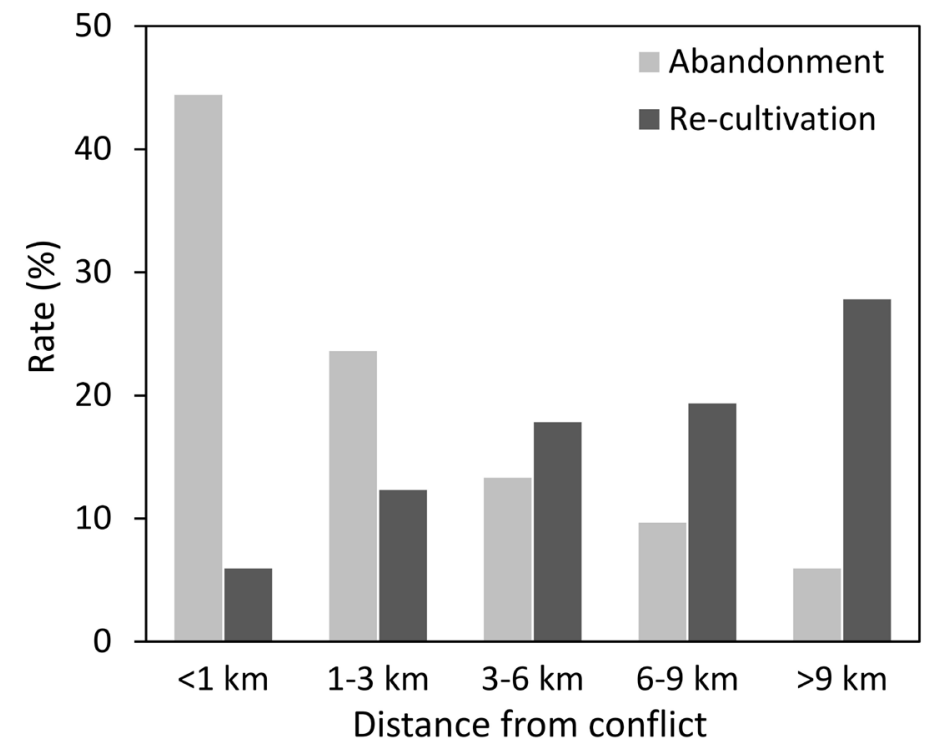

Figure 3 Agricultural land abandonment and re-cultivation rates at different distances to conflicts. If the conflict events occurred within a settlement, the distance was calculated from the border of the settlement.

\subsection{Local effects of the armed conflicts}

Our models confirmed a strong correlation between the distance to armed conflicts and agriculture land abandonment. Both logit and panel regression models suggested that areas closer to armed conflicts had a higher probability of agricultural land abandonment (Figure 4). During the First Chechen War, agricultural land $<1 \mathrm{~km}$ of a conflict had the highest land abandonment probability. For instance, the probability of agricultural land abandonment in relation to three conflict events was $43.7 \%$ if these events were located within $1 \mathrm{~km}$, while the 
probabilities of abandonment were $27.5 \%$ and $5.7 \%$ for $1-2 \mathrm{~km}$ and $>8 \mathrm{~km}$ distance respectively

(Figure 4, model I-1). Similarly, during the Second Chechen War, the fixed-effects model showed that agricultural lands that $<1 \mathrm{~km}$ from a conflict had the highest abandonment probability (Figure 4, model II). For instance, the abandonment probability of three conflict events decreased from $1 \mathrm{~km}(31.7 \%)$ to $>8 \mathrm{~km}(8.2 \%)$ (Figure 4, model II-1). Regardless of the conflict event number, the probability of agricultural land abandonment during the First Chechen War decreased from $1 \mathrm{~km}(44.7 \%)$ to $>8 \mathrm{~km}(6.7 \%)$ (Figure 4, model I-1). During the Second Chechen War the probability of abandonment decreased from $1 \mathrm{~km}(32.5 \%)$ to $>8 \mathrm{~km}$ (8.3\%) using fixed-effects model (Figure 4, model II-1), and decreased from $1 \mathrm{~km}(25.4 \%)$ to $>8$ km (7.3\%) using random-effects model (Figure 4, model III-1). Unlike agricultural land abandonment, re-cultivation was more likely at longer distances from conflicts. For example, the probability of re-cultivation was five times higher when $16 \mathrm{~km}$ afar from conflicts than within 2 km (Figure 5).

\subsection{Effects of conflict intensity}

The effects of conflict intensity on agriculture land abandonment varied among conflicts, location, intensity measurement, and models used. The results from the First Chechen War suggested a higher chance of abandonment in agricultural areas that experienced a higher number of conflicts (Figure 4, model I-1). For instance, the probability of abandonment within $1 \mathrm{~km}$ of conflicts increased from $38.2 \%$ to $56.8 \%$ for one versus more than nine conflicts respectively. However, the number of conflicts only mattered within $6 \mathrm{~km}$ of conflicts. Similarly, the probability of abandonment increased with the increase of civilian casualties and total casualties, but the magnitude of their effects was lower than for the number of conflicts (Figure 4, model I-2, I-3). Lastly, there were no significant differences in the abandonment probability when there were more than ten casualties (Figure 4, model I-2, I-3). 
During the Second Chechen War, our fixed effect models showed that higher numbers of conflicts resulted in higher abandonment probabilities for agricultural lands within $3 \mathrm{~km}$ of conflicts (Figure 4, model II-1). However, in the random-effects model, only agricultural lands that were within 1-5 $\mathrm{km}$ from conflicts had significantly higher abandonment probabilities when there were more conflicts (Figure 4, model III-1). We also found a slight difference between our fixed-effects and random-effects model that included civilian casualties to explain land abandonment. More civilian casualties led to higher abandonment probabilities in the random-effects models (Figure 4, model III-2) but not the fixed-effects models (Figure 4, model II-2) for agricultural land that was within $3 \mathrm{~km}$ of conflicts. In general, casualties were positively linked to agricultural land abandonment in both models, but for some distances, the relationship was negative (Figure 4, model II-3, III-3). 

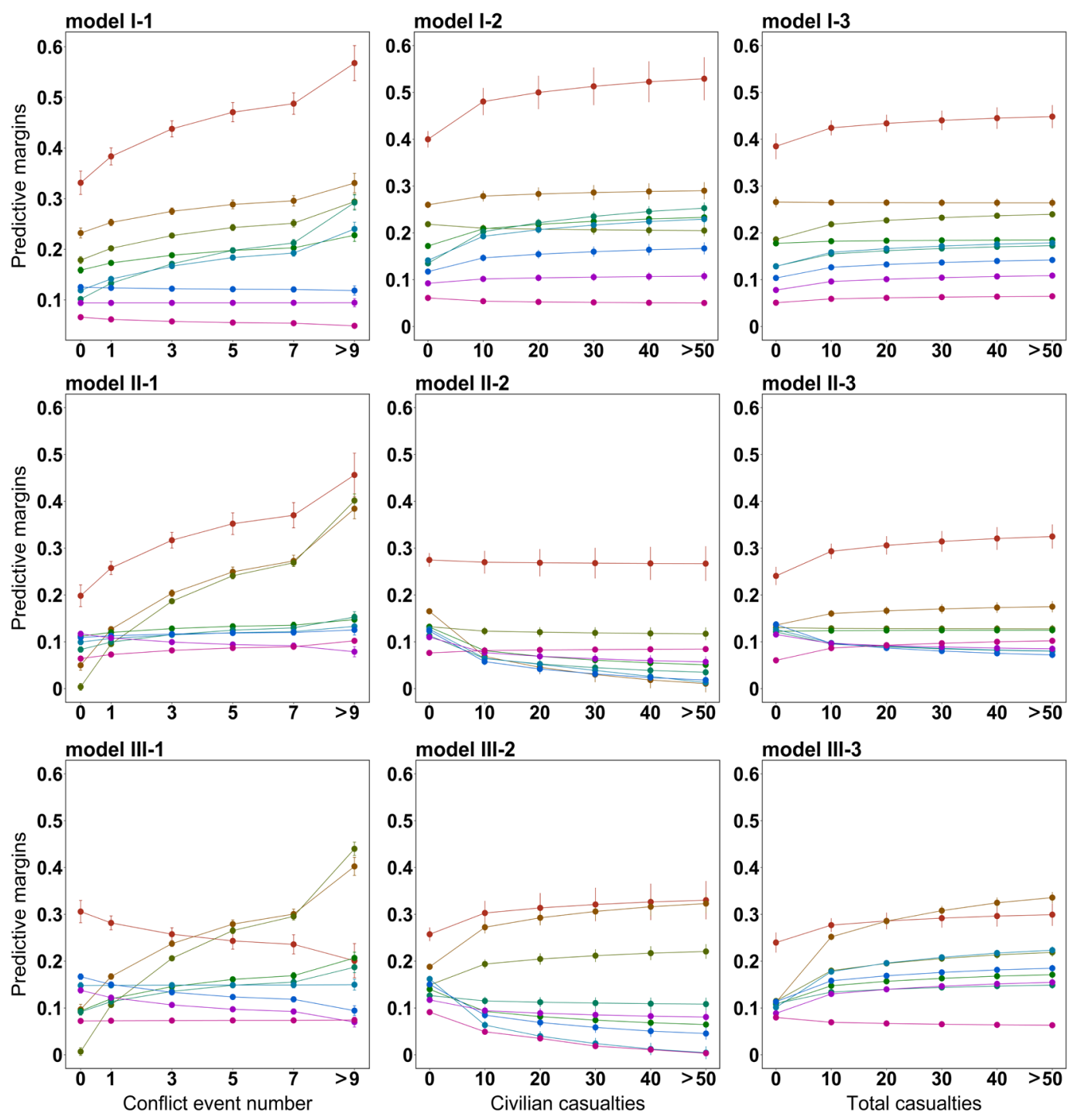

model III-3

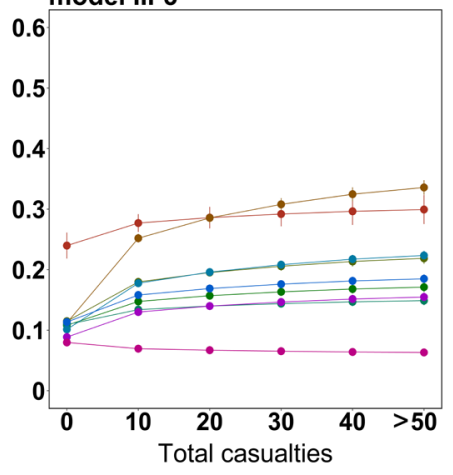

Distance $(\mathrm{km}) \bullet<1-1-2 \bullet-2-3 \bullet-3-4-4-5 \bullet-5-6 \bullet-6-7-7-8 \bullet->8$

Figure 4 Marginal effects of armed conflicts on agricultural land abandonment at different distances to conflicts, and for different numbers of conflict events, civilian casualties and total casualties, with 95\% confidence intervals. Model I shows the marginal effects of the First Chechen War using logit model, model II uses fixed-effects model and model III uses random-effects model for the Second Chechen War. 


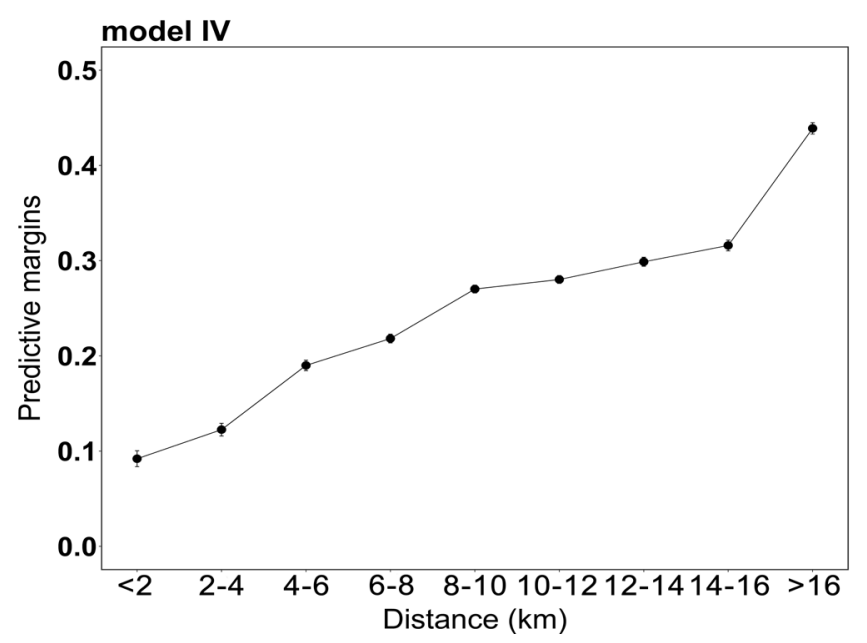

Figure 5 Marginal effects of conflicts on agricultural re-cultivation at different distances from conflicts, with $95 \%$ confidence intervals.

\section{Discussion}

We applied logistic and panel regression models to investigate the relationship between armed conflicts and agricultural land-use change in the northern Caucasus. We found that areas closer to armed conflicts, and areas with higher conflict intensity had higher rates of agricultural land abandonment. We also found higher re-cultivation rates of abandoned fields father away from conflicts in the post-conflict era, suggesting the long-lasting effects of the conflicts. While our methods did not allow to identify causal mechanism of armed conflicts directly, the patterns that we found are consistent with several direct and indirect causes of armed conflicts on agricultural land-use in the northern Caucasus.

We found that rates of abandonment were higher in areas that were closer to conflict events. During the First Chechen War, for example, agricultural land that was within $1 \mathrm{~km}$ of conflict had the highest agricultural land abandonment probability (predictive margins $>40 \%$, Figure 4). This finding is similar to the previous studies in Syria (Eklund et al., 2017) and Nagorno-Karabakh in the southern Caucasus (Baumann et al., 2015). It is likely that both 
displacement and casualties of former state and collective farmers in Chechnya and Ingushetia were important reasons (Sakwa, 2005; Witmer and O'Loughlin, 2011). Though no precise figure of internally displaced persons for Chechnya and Ingushetia exists, about 600,000 civilians had been forced from their homes as of the end of 1999 (USCR, 2000). The majority of the internally displaced persons were displaced within Chechnya and a substantial number of them (up to 250,000) fled to neighboring Ingushetia during 1999-2000 (Norwegian Refugee Council, 2001). In addition, the Chechen Wars limited access to agricultural inputs such as seeds, tools, irrigation and veterinary treatment. The unstable supply and the high cost of the agricultural inputs during wartime discouraged the usage of farmlands (ICRC, 2007). Lastly, widespread water and soil pollution impeded agricultural activities (Shakhtimirov et al., 2012).

We found that agricultural lands that experienced higher conflict intensity had higher rates of abandonment, but the predicted abandonment probability varied depending on how conflict intensity was measured. Among our three measures, the number of conflict events was positively correlated to agricultural land abandonment (Figure 4), similar to what happened in paramilitary groups-dominated areas in Columbia (Sánchez-Cuervo and Aide, 2013). An explanation for this may be that farmers change their behaviors in response to frequent conflicts (Voors et al., 2012). To reduce the risks, farmers who experience multiple armed conflicts leave fields fallow and reduce agricultural activities (Arias et al., 2012). Persistent armed conflicts can also result in higher rates of poverty that prevent post-conflict agricultural reconstruction, such as in Rwanda (Serneels and Verpoorten, 2015). Interestingly, we found that the effects of conflict number on agricultural land abandonment differed somewhat between the First and the Second Chechen War. During the First Chechen War, the spatial spillover effects of conflict number reached as far as $6 \mathrm{~km}$, but during the Second Chechen War it was only up to $3 \mathrm{~km}$. 
While the effects of the number of conflict events were fairly uniform, the effects of citizen casualties and total casualties on agricultural land abandonment rates were not (Figure 4). Where farmlands were within $1 \mathrm{~km}$ of conflicts, more casualties resulted in more agricultural land abandonment. For farmlands that were more than $1 \mathrm{~km}$ afar, however, there was no general pattern of the influence of casualties on agricultural land abandonment. Two factors might explain this. First, casualty information, especially civilian casualties, may be less relevant to rural land-use change, because a large proportion of the civilian death in the northern Caucasus was caused by terrorist attacks (O'Loughlin et al., 2011). For instance, one of the events with the highest number of civilian casualties, the Beslan School attack in 2004, resulted in 334 deaths, including 156 children, but there was no prolonged military standoff. Second, though the UCDP is a state-of-art dataset, casualty estimates in the northern Caucasus may be incomplete (Weidmann, 2015).

We found in general little re-cultivation after the Chechen Wars, but the probability of re-cultivation was lowest near prior conflicts (Figure 3, 5). Very few studies have examined post-conflict agricultural land-use change (Baumann and Kuemmerle, 2016). We found longlasting effects of armed conflicts on agricultural land-use in the northern Caucasus. Though a significant number of people has returned to Chechnya (e.g. 16,170 in 2003), either voluntarily or due to the shutdown of tent camps and other pressures in Ingushetia (European Commision, 2004), the re-cultivation rates in Chechnya were low. The limited investment in agriculture might be one of the reasons for low re-cultivation rates. After Russia's declaration of victory in 2009, the insurgency in Chechnya has been largely suppressed (Figure 2). Concomitantly, large reconstruction funding from the Russian federal government was given to the new government (Russell, 2011; Zabyelina, 2013). However, the focus of the reconstruction efforts was to rebuild the capital Grozny, as well as infrastructure and the petroleum industry, while the agricultural 
sector received less attention (IDMC, 2013). The re-construction of transportation infrastracture might have though improved market access thereby encrouaging re-cultivation. However, we could not quantify such effects because no relibale information on road destruction during the wars and reconstruction thereafter, were available to us. Last, the lack of institutionalized land ownership remains a factor that limits agriculture in the northern Caucasus (Kolosov et al., 2017). Land disputes among farmers, ethnic groups, district municipalities, and big agricultural holdings often escalated into tensions and clashes (International Crisis Group, 2015; Koehler et al., 2017).

In addition to conflicts and their intensity, other variables influenced agricultural land abandonment as well, but the magnitudes of their coefficients were small. The effects of elevation, slope, and soil quality on abandonment were positive, while the distance to nearest settlement and nearest roads had negative effects in both the logistic and panel regression models (Table S1, and S3, Supplementary material). Unlike other Soviet regions where soil quality played an important role in agricultural land abandonment (Prishchepov et al., 2013), we found only small effects (Figure S1, Supplementary material). This may be partly due to relatively homogeneous soil quality in our study area, and partly due to the coarse resolution of the European Soil Database $(1 \mathrm{~km})$ that we used. The marginal effects of the distance to the nearest settlement showed that the farther from a settlement and a road, the less likely agricultural land abandonment during the First and the Second Chechen War (Figure S2 and S3, Supplementary material). This might be explained by the fact that a high number of conflict events occurred in the settlements and along the roads, especially along the Caucasian Federal Highway (O'Loughlin and Witmer, 2011).

Although we included variables that are commonly used to explain agricultural landuse change, we acknowledge that our variable selection was somewhat limited. For example, 
we did not include demographical variables in the models because no reliable and spatially detailed dataset was available to us for the northern Caucasus. We also did not include information on landmines, unexploded ordnance (UXO), and abandoned explosive ordnance $(\mathrm{AXO})$ in our models because information where they are located and in what quantity remains limited in the northern Caucasus, especially in Chechnya (ICBL-CMC, 2018). For example, in 2010, Russia's Presidential Special Envoy to the Caucasus claimed that mines affected $14 \mathrm{~km}^{2}$ of land in Chechnya (Russia Today, 2010) while Chechen officials and human rights organizations previously estimated that $165 \mathrm{~km}^{2}$ of farmland was mined (Caucasian Knot, 2009). Last, allochthonous drivers such economic globalization may have influenced land-use change in the northern Caucasus. However, we presume that the influence of the global economy to regional economy was relatively even across the northern Caucasus and thus did not affect our withinregion analyses.

Several sources of uncertainty in our models need mentioning. First, our agricultural land-use change map included some errors that may affect the marginal effects estimated. However, we presume that the mapping errors were randomly distributed and the influence of errors thus did not affect the comparison of the effect of armed conflict across different conflict distances. Second, during the First Chechen War, annual satellite imagery was not available when we finalized the maps, making it difficult to separate the effects of the collapse of the Soviet Union from the effects of the conflicts. Since then, "no-Payload Correction" Landsat TM imagery has been added to the USGS's data portal that has the potential to fill the data gap in the 1990s. Third, our analysis focused on one Landsat footprint only, and did not cover the entire Caucasus, which may have revealed land-use displacement. To the best of our knowledge, such effects were limited in the northern Caucasus though, partly because there are very few un-cultivated lands that are suitable for agricultural production near IDP camps and 
host families, and partly because of the scarce supply and high cost of agricultural inputs (Norwegian Refugee Council, 2001). Fourth, analysis at contiguous ownership and management units (fields) can provide an improved representation of landscape pattern over existing pixelbased models, yet field boundary is rarely available at a large scale (Sohl et al., 2017). We tested our models using the objects produced by Yin et al. (2018) as analysis unit and the results showed a similar pattern as that using pixel as analysis unit (Figure S4, Supplementary material). Fifth and last, spatial autocorrelation can lead to biased standard errors in models of land-use change. In our models, with a binary dependent variable and a large number of observations, we are not aware of an approach to efficiently add spatial lags. However, a number of features of our analysis limit the potential for spatially autocorrelated errors: a) we used $5 \%$ of the pixels, which should reduce spatial relationship between observations, b) we included a rich set of co-variables that minimized potential for spatial unobservables, and c) we included regional dummy and geolocation variables, which absorb potential unobserved variation for variables within each district.

In summary, we found a higher probability of agricultural land abandonment in areas closer to conflicts and with higher conflict intensity. Our study also highlighted the long-lasting legacy of the armed conflicts on land-use in that we found limited re-cultivation of abandoned agriculture in areas closer to the armed conflicts. This, however, does not mean that the reconstruction of the agricultural sector will not happen in the future. Our findings have important political and socio-economic implications. Understanding agricultural land-use change and identifying spatial and temporal patterns in war-torn areas provide references for post-conflict agricultural management thus supporting returning refugees, local farmers, and allow to redirect reconstruction funding more effectively. Overall, our study provides a better understanding of the Chechen Wars and agricultural land-use change in the northern Caucasus, 
which may be applicable when predicting the consequences of armed conflicts on land-use in other war-torn areas.

\section{References}

Adams, C., Ide, T., Barnett, J., Detges, A., 2018. Sampling bias in climate-conflict research. Nat. Clim. Chang. 1-4. doi:10.1038/s41558-018-0068-2

Afonin, A.N., Greene, S.L., Dzyubenko, N.I., Frolov, A.N., 2008. Interactive Agricultural Ecological Atlas of Russia and Neighboring Countries. Economic Plants and their Diseases [WWW Document]. URL http://www.agroatlas.ru

Alix-Garcia, J., Bartlett, A., Saah, D., 2013. The landscape of conflict: IDPs, aid and land-use change in Darfur. J. Econ. Geogr. 13, 589-617. doi:10.1093/jeg/lbs044

Alix-Garcia, J., Kuemmerle, T., Radeloff, V.C., 2012. Prices, Land Tenure Institutions, and Geography: A Matching Analysis of Farmland Abandonment in Post-Socialist Eastern Europe. Land Econ. 88, 425-443. doi:10.3368/le.88.3.425

Allison, P.D., 2009. Fixed effects regression models, Quantitative Applications in the Social Sciences. SAGE Publications Inc.

Arias, M.A., Ibañez, A.M., Zambrano, A., 2012. Agricultural production amid conflict: the effects of shocks, uncertainty, and governance of non-state armed actors. Doc. Cede, 201234 76. doi:10.1017/CBO9781107415324.004

Arima, E.Y., Richards, P., Walker, R., Caldas, M.M., 2011. Statistical confirmation of indirect land use change in the Brazilian Amazon. Environ. Res. Lett. 6. doi:10.1088/17489326/6/2/024010

Austin, J.E., Bruch, C.E., 2000. The environmental consequences of war: Legal, economic, and scientific perspectives. Cambridge University Press.

Baechler, G., 1996. Rwanda: The roots of tragedy, battle for elimination on an ethno-political and ecological basis, in: Baechler, G., Spillmann, K.R. (Eds.), Environmental Degradation as a Cause of War, Vol II. Verlag Rueegger, Zurich, pp. 461-502.

Baumann, M., Kuemmerle, T., 2016. The impacts of warfare and armed conflict on land systems. J. Land Use Sci. 11, 672-688. doi:10.1080/1747423X.2016.1241317

Baumann, M., Radeloff, V.C., Avedian, V., Kuemmerle, T., 2015. Land-use change in the Caucasus during and after the Nagorno-Karabakh conflict. Reg. Environ. Chang. 15, 17031716. doi:10.1007/s10113-014-0728-3 
Biswas, A., 2001. Scientific assessment of the long-term environmental consequences of war, in: Austin, J.E., Carl E., B. (Eds.), The Environmental Consequences of War: Legal, Economic, and Scientific Perspectives. Cambridge University Press, Cambridge, UK, pp. 203-315.

Brück, T., 2001. Macroeconomic Effects of the War in Mozambique. SSRN Electron. J. doi:10.2139/ssrn.259490

Butsic, V., Baumann, M., Shortland, A., Walker, S., Kuemmerle, T., 2015. Conservation and conflict in the Democratic Republic of Congo: The impacts of warfare, mining, and protected areas on deforestation. Biol. Conserv. 191, 266-273.

doi:10.1016/j.biocon.2015.06.037

Butsic, V., Munteanu, C., Griffiths, P., Knorn, J., Radeloff, V.C., Lieskovský, J., Mueller, D., Kuemmerle, T., 2017. The effect of protected areas on forest disturbance in the Carpathian Mountains 1985-2010. Conserv. Biol. 31, 570-580. doi:10.1111/cobi.12835

Caucasian Knot, 2013. Khloponin: 80\% of corruption crimes in the Caucasus are connected with land issues [WWW Document]. URL http://www.kavkaz-uzel.eu/articles/221444/ (accessed 8.20.08).

Caucasian Knot, 2009. MoE sappers to demine arable lands in Chechnya [WWW Document]. URL http:/ / www.eng.kavkaz-uzel.eu/articles/9766/ (accessed Aug 2018)

Darwish, R., Farajalla, N., Masri, R., 2009. The 2006 war and its inter-temporal economic impact on agriculture in Lebanon. Disasters. doi:10.1111/j.1467-7717.2008.01091.x

Devitt, C., Tol, R.S.J., 2012. Civil war, climate change, and development: A scenario study for sub-saharan Africa. J. Peace Res. 49, 129-145. doi:10.1177/0022343311427417

Douarin, E., Litchfield, J., Sabates-Wheeler, R., 2012. War Legacies, Welfare and Livelihoods in Rural Areas: The Case of Kosovo. J. Agric. Econ. 63, 201-222. doi:10.1111/j.14779552.2011.00328.x

Dupuy, K., Gates, S., Nygard, H.M., Rudolfsen, I., Strand, H., Urdal, H., 2017. Trends in armed conflict, 1946-2016. Peace Res. Inst. Oslo August, 1-5.

Eklund, L., Degerald, M., Brandt, M., Prishchepov, A. V., Pilesjö, P., 2017. How conflict affects land use: Agricultural activity in areas seized by the Islamic State. Environ. Res. Lett. 12. doi:10.1088/1748-9326/aa673a

European Commision, 2004. Humanitarian aid for the victims of the Chechnya conflict.

FAO, 2016. FAOSTAT, Methods \& standards [WWW Document]. URL http://www.fao.org/ag/agn/nutrition/Indicatorsfiles/ Agriculture.pdf (accessed 03.03.16)

FAO, 2009. Russian Federation: Analysis of the Agribusiness Sector in Southern Russia. Report Series No. 13, FAO Investment Centre/EBRD Cooperation Program. Rome, Italy.

FAO, 2000. The state of food and agriculture 2000. 
Farr, T.G., Rosen, P.A., Caro, E., Crippen, R., Duren, R., Hensley, S., Kobrick, M., Paller, M., Rodriguez, E., Roth, L., Seal, D., Shaffer, S., Shimada, J., Umland, J., Werner, M., Oskin, M., Burbank, D., Alsdorf, D.E., 2007. The shuttle radar topography mission. Rev. Geophys. 45. doi:10.1029/2005RG000183

Formoli, T.A., 1995. Impacts of the Afghan-Soviet war on Afghanistan's environment. Environ. Conserv. doi:10.1017/S0376892900034093

Frayer, J., Sun, Z., Müller, D., Munroe, D.K., Xu, J., 2014. Analyzing the drivers of tree planting in Yunnan, China, with Bayesian networks. Land use policy 36, 248-258. doi:10.1016/j.landusepol.2013.08.005

Gates, S., Hegre, H., Nygård, H.M., Strand, H., 2012. Development Consequences of Armed Conflict. World Dev. 40, 1713-1722. doi:10.1016/j.worlddev.2012.04.031

Gaynor, K.M., Fiorella, K.J., Gregory, G.H., Kurz, D.J., Seto, K.L., Withey, L.S., Brashares, J.S., 2016. War and wildlife: linking armed conflict to conservation. Front. Ecol. Environ. 14, 533-542. doi:10.1002/fee.1433

Gbanie, S., Griffin, A., Thornton, A., Gbanie, S.P., Griffin, A.L., Thornton, A., 2018. Impacts on the Urban Environment: Land Cover Change Trajectories and Landscape Fragmentation in Post-War Western Area, Sierra Leone. Remote Sens. 10, 129. doi:10.3390/rs10010129

Geist, H.J., Lambin, E.F., 2002. Proximate Causes and Underlying Driving Forces of Tropical DeforestationTropical forests are disappearing as the result of many pressures, both local and regional, acting in various combinations in different geographical locations. Bioscience 52, 143-150. doi:10.1641/0006-3568(2002)052[0143:pcaudf]2.0.co;2

Gerges, M.A., 1993. On the impacts of the 1991 Gulf War on the environment of the region: General observations. Mar. Pollut. Bull. 27, 305-314. doi:10.1016/0025-326X(93)90038-L

Gorsevski, V., Geores, M., Kasischke, E., 2013. Human dimensions of land use and land cover change related to civil unrest in the Imatong Mountains of South Sudan. Appl. Geogr. 38, 64-75. doi:10.1016/j.apgeog.2012.11.019

Grinfelde, I., Mathijs, E., 2004. Agricultural land abandonment in Latvia: An econometric analysis of farmers' choice, in: Agricultural Economics Society Annual Conf. South Kensington, Imperial College, pp. 1-24.

Gunya, A., 2017. Land reforms in Post-Socialist mountain regions and their Impact on land use management: a case study from the Caucasus. J. Alp. Res. 1-15.

Hendrie, B., 1994. Relief aid behind the lines: the cross-border operation in Tigray, in: Macrae, J., Zwi, A. (Eds.), War and Hunger: Rethinking International Responses to Complex Emergencies. Zed Books, London, pp. 125-138.

Holland, E.C., Witmer, F.D.W., O'Loughlin, J., 2018. The decline and shifting geography of violence in Russia's North Caucasus, 2010-2016. Eurasian Geogr. Econ. 1-29. doi:10.1080/15387216.2018.1438905 
ICBL-CMC, 2018. Landmine \& Cluster Munition: Russian Federation Mine Action [WWW Document]. URL http://www.the-monitor.org/en-gb/reports/2018/russianfederation/mine-action.aspx (accessed Aug 2018)

ICRC, 2007. Farming through conflict [WWW Document]. URL https://www.icrc.org/eng/assets/files/other/farming_through_conflict.pdf (accessed Aug 2018)

IDMC, 2018. Profile on Internal Displacement: Russian Federation [WWW Document]. URL http:/ / www.internal-displacement.org/ (accessed Aug 2018)

IDMC, 2013. IDPs increasingly neglected despite continuing needs [WWW Document]. URL http:// www.internal-displacement.org/ europe-the-caucasus-and-central-asia/russianfederation/2013/idps-increasingly-neglected-despite-continuing-needs (accessed Mar 2018)

International Crisis Group, 2015. North Caucasus: The Challenges of integration (IV): Economic and social imperatives [WWW Document]. URL https://www.crisisgroup.org/europecentral-asia/caucasus/russianorth-caucasus/north-caucasus-challenges-integration-iveconomic-and-social-imperatives (accessed 8.25.18).

Ioffe, G., Nefedova, T., 2000. Areas of crisis in Russian agriculture: A geographic perspective. Post. Sov. Geogr. Econ. 41, 288-305.

Ioffe, G., Nefedova, T., Zaslavsky, I., 2004. From spatial continuity to fragmentation: The case of Russian farming. Ann. Assoc. Am. Geogr. 94, 913-943. doi:10.1111/j.1467-

8306.2004.00441.x

Jaafar, H.H., Woertz, E., 2016. Agriculture as a funding source of ISIS: A GIS and remote sensing analysis. Food Policy 64, 14-25. doi:10.1016/J.FOODPOL.2016.09.002

Keen, D., 2000. The political economy of war, in: Stewart, F., Fitzgerald, V. (Eds.), War and Underdevelopment: Volume 1: The Economic and Social Consequences of Conflict. Oxford University Press, pp. 39-66. doi:10.1093/acprof:oso/9780199241866.003.0003

Kim, K.C., 1997. Preserving Biodiversity in Korea's Demilitarized Zone. Science (80-. ). 278, $242-$ 243. doi:10.1126/ science.278.5336.242

Koehler, J., Gunya, A., Tenov, T., 2017. Governing the local in the North Caucasus. Eurasian Geogr. Econ. 58, 502-532. doi:10.1080/15387216.2017.1410440

Kolosov, V.A., Vendina, O.I., Gritsenko, A.A., Glezer, O.B., Zotova, M. V., Sebentsov, A.B., Panin, A.N., 2017. Economic and social reforms in the North Caucasus: Goals, limitations, problems, and results. Reg. Res. Russ. 7, 259-270. doi:10.1134/S2079970517030029

Kuemmerle, T., Müller, D., Griffiths, P., Rusu, M., 2009. Land use change in Southern Romania after the collapse of socialism. Reg. Environ. Chang. 9, 1-12. doi:10.1007/s10113-008-0050-z 
Levin, N., Ali, S., Crandall, D., 2018. Utilizing remote sensing and big data to quantify conflict intensity: The Arab Spring as a case study. Appl. Geogr. 94, 1-17.

doi:10.1016/J.APGEOG.2018.03.001

Li, Q., Wen, M., 2005. The Immediate and Lingering Effects of Armed Conflict on Adult Mortality: A Time-Series Cross-National Analysis. J. Peace Res. 42, 471-492. doi:10.1177/0022343305054092

Linke, A.M., O'Loughlin, J., McCabe, J.T., Tir, J., Witmer, F.D.W., 2015. Rainfall variability and violence in rural Kenya: Investigating the effects of drought and the role of local institutions with survey data. Glob. Environ. Chang. 34, 35-47. doi:10.1016/j.gloenvcha.2015.04.007

Martin, P.S., Szuter, C.R., 1999. War zones and game sinks in Lewis and Clark's West. Conserv. Biol. 13, 36-45. doi:10.1046/j.1523-1739.1999.97417.x

Meyfroidt, P., Schierhorn, F., Prishchepov, A. V., Müller, D., Kuemmerle, T., 2016. Drivers, constraints and trade-offs associated with recultivating abandoned cropland in Russia, Ukraine and Kazakhstan. Glob. Environ. Chang. 37, 1-15. doi:10.1016/j.gloenvcha.2016.01.003

Müller, D., Kuemmerle, T., Rusu, M., Griffiths, P., 2009. Lost in transition: determinants of postsocialist cropland abandonment in Romania. J. Land Use Sci. 4, 109-129. doi:10.1080/17474230802645881

Nita, M.D., Munteanu, C., Gutman, G., Abrudan, I.V., Radeloff, V.C., 2018. Widespread forest cutting in the aftermath of World War II captured by broad-scale historical Corona spy satellite photography. Remote Sens. Environ. 204, 322-332. doi:10.1016/J.RSE.2017.10.021

Norwegian Refugee Council, 2001. Profile of internal displacement: Russian Federation Compilation of the information available in the Global IDP Database of the Norwegian Refugee Council. Geneva.

O'Loughlin, J., Holland, E.C., Witmer, F.D.W., 2011. The changing geography of violence in Russia's North Caucasus, 1999-2011: Regional trends and local dynamics in Dagestan, Ingushetia, and Kabardino-Balkaria. Eurasian Geogr. Econ. 52, 596-630. doi:10.2747/15397216.52.5.596

O'Loughlin, J., Witmer, F.D.W., 2012. The diffusion of violence in the North Caucasus of Russia, 1999-2010. Environ. Plan. A 44, 2379-2396. doi:10.1068/a44366

O'Loughlin, J., Witmer, F.D.W., 2011. The localized geographies of violence in the North Caucasus of Russia, 1999-2007. Ann. Assoc. Am. Geogr. 101, 178-201. doi:10.1080/00045608.2010.534713

OCHA, 2005. UN Office for the Coordination of Humanitarian Affairs (OCHA) in the Russian Federation: Inter-agency transitional workplan for the North Caucasus 2006.

OpenStreetMap contributors, 2017. Planet dump retrieved from https://www.openstreetmap.org. 
Ordway, E.M., 2015. Political shifts and changing forests: Effects of armed conflict on forest conservation in Rwanda. Glob. Ecol. Conserv. 3, 448-460. doi:10.1016/j.gecco.2015.01.013

Osawa, T., Kohyama, K., Mitsuhashi, H., 2016. Multiple factors drive regional agricultural abandonment. Sci. Total Environ. 542, 478-483. doi:10.1016/j.scitotenv.2015.10.067

Panagos, P., Van Liedekerke, M., Jones, A., Montanarella, L., 2012. European Soil Data Centre: Response to European policy support and public data requirements. Land use policy 29, 329-338. doi:10.1016/j.landusepol.2011.07.003

Price, A.R.., Downing, N., Fowler, S.., Hardy, J.., Le Tissier, M., Mathews, C.P., McGlade, J.M., Medley, P.A.H., 1994. The 1991 Gulf War: Environmental Assessments of IUCN and Collaborators. A Marine Conservation and Development Report. Gland, Switzerland.

Prishchepov, A. V., Müller, D., Dubinin, M., Baumann, M., Radeloff, V.C., 2013. Determinants of agricultural land abandonment in post-Soviet European Russia. Land use policy 30, 873884. doi:10.1016/j.landusepol.2012.06.011

Prishchepov, A. V., Radeloff, V.C., Baumann, M., Kuemmerle, T., Müller, D., 2012. Effects of institutional changes on land use: agricultural land abandonment during the transition from state-command to market-driven economies in post-Soviet Eastern Europe. Environ. Res. Lett. 7. doi:Artn 024021 10.1088/1748-9326/7/2/024021

Rasmussen, L.V., Rasmussen, K., Reenberg, A., Proud, S., 2012. A system dynamics approach to land use changes in agro-pastoral systems on the desert margins of Sahel. Agric. Syst. 107, 56-64. doi:10.1016/J.AGSY.2011.12.002

Rosstat, 2016. Central statistical database. Federal service of state statistics of the Russian Federation.

Russell, J., 2011. Kadyrov's Chechnya-template, test or trouble for Russia's regional policy? Eur. - Asia Stud. 63, 509-528. doi:10.1080/09668136.2011.557541

Russell, J., 2005. Terrorists, bandits, spooks and thieves: Russian demonisation of the Chechens before and since 9/11. Third World Q. 26, 101-116. doi:10.1080/0143659042000322937

Russia Today, 2010. Medvedev emphasizes vision of Chechnya's future with personal visit [WWW Document]. URL https://on.rt.com/106i (accessed Aug 2018)

Sakwa, R., 2005. Chechnya: From past to future, Chechnya: From Past to Future. doi:10.7135/UPO/9781843313618

Sánchez-Cuervo, A.M., Aide, T.M., 2013. Consequences of the armed conflict, forced human displacement, and land abandonment on forest cover change in Colombia: A multi-scaled analysis. Ecosystems 16, 1052-1070. doi:10.1007/s10021-013-9667-y

Serneels, P., Verpoorten, M., 2015. The impact of armed conflict on economic performance: Evidence from Rwanda. J. Conflict Resolut. 59, 555-592. doi:10.1177/0022002713515409 
Seto, K.C., Kaufmann, R.K., 2003. Modeling the Drivers of Urban Land Use Change in the Pearl River Delta, China: Integrating Remote Sensing with Socioeconomic Data. Land Econ. 79, 106-121. doi:10.2307/3147108

Shakhtimirov, I.Y., Isaeva, S.K., Askhabova, K.N., Shuipov, K.A.-V., 2012. Monitoring of persisitent organic pllutants in the soil of the Chechen Republic. South Russ. Ecol. Dev. 7, 121-124.

Sohl, T., Dornbierer, J., Wika, S., Sayler, K., Quenzer, R., 2017. Parcels versus pixels: modeling agricultural land use across broad geographic regions using parcel-based field boundaries. J. Land Use Sci. doi:10.1080/1747423X.2017.1340525

Stevens, K., Campbell, L., Urquhart, G., Kramer, D., Qi, J., 2011. Examining complexities of forest cover change during armed conflict on Nicaragua's Atlantic Coast. Biodivers. Conserv. 20, 2597-2613. doi:10.1007/s10531-011-0093-1

Strandow, D., Findley, M.G., Young., J.K., 2014. Foreign aid and the intensity of violent armed conflict [WWW Document]. URL http://www.michael-

findley.com/uploads/2/0/4/5/20455799/foreign_aid_violent_conflict_strandow-findleyyoung.pdf (accessed May 2018)

Sundberg, R., Melander, E., 2013. Introducing the UCDP Georeferenced Event Dataset. J. Peace Res. 50, 523-532. doi:10.1177/0022343313484347

Suthakar, K., Bui, E.N., 2008. Land use/cover changes in the war-ravaged Jaffna Peninsula, Sri Lanka, 1984-early 2004. Singap. J. Trop. Geogr. 29, 205-220. doi:10.1111/j.14679493.2008.00329.x

Tomuschat, C., Lux de Coti, O., Balsells Tojo, A., 1999. Guatemala memory of silence. Guatemalan Commission for Historical Clarification (CEH) [WWW Document]. URL http:/ / www.b92.net/trr/eng/doc/guatemala-final .doc (accessed Oct 2018)

Trevelyan, J., Tilli, S., Parks, B.D., Chiat, T.H., 2002. Farming minefields: economics of remediating land with moderate landmine and UXO contamination.

UNHCR, 2000. Global Report 2000 Russian Federation [WWW Document]. URL http:/ / www.unhcr.org/3e23eb6f0.pdf (accessed Aug 2018)

United Nations, 2012. Land and conflict: Toolkit and guidance for preventing and managing land and natural resources conflict.

Unruh, J., Shalaby, M., 2012. A volatile interaction between peacebuilding priorities: Road infrastructure (re)construction and land rights in Afghanistan. Prog. Dev. Stud. doi:10.1177/146499341101200103

Urdal, H., 2005. People vs. Malthus: Population pressure, environmental degradation, and armed conflict revisited. J. Peace Res. doi:10.1177/0022343305054089

USCR, 2000. U.S. Committee for Refugees World Refugee Survey 2000: Country report Russian Federation. 
Uzun, V., Saraikin, V., Gataulina, E., Shagaida, N., Yanbykh, R., Mary, S., Gomez y Paloma, S., 2014. Prospects of the farming sector and rural development in view of food security: The case of the Russian Federation.

Vendina, O., Belozerov, V., Gustafson, A., 2007. The Wars in Chechnya and Their Effects on Neighboring Regions. Eurasian Geogr. Econ. 48, 178-201. doi:10.2747/1538-7216.48.2.178

Vité, S., 2009. Typology of armed conflicts in international humanitarian law: legal concepts and actual situations | International Committee of the Red Cross [WWW Document]. URL https:/ / www.icrc.org/en/international-review/article/typology-armed-conflictsinternational-humanitarian-law-legal-concepts (accessed May 2018)

Voors, M.J., Nillesen, E.E.M., Verwimp, P., Bulte, E.H., Lensink, R., Van Soest, D.P., 2012. Violent conflict and behavior: A field experiment in Burundi. Am. Econ. Rev. 102, 941-964. doi:10.1257/aer.102.2.941

Weidmann, N.B., 2015. On the Accuracy of Media-based Conflict Event Data. J. Conflict Resolut. 59, 1129-1149. doi:10.1177/0022002714530431

Westing, A.H., 1976. Ecological Consequences of the Second Indochina War. Taylor \& Francis.

Williams, B.G., 2001. The Russo-Chechen War: A threat to stability in the Middle East and Eurasia? Middle East Policy 8, 128. doi:10.1111/1475-4967.00012

Wilson, S.A., Wilson, C.O., 2013. Modelling the impacts of civil war on land use and land cover change within Kono District, Sierra Leone: a socio-geospatial approach. Geocarto Int. 28, 476-501. doi:10.1080/10106049.2012.724456

Witmer, F.D.W., 2008. Detecting war-induced abandoned agricultural land in northeast Bosnia using multispectral, multitemporal Landsat TM imagery. Int. J. Remote Sens. 29, 38053831. doi:10.1080/01431160801891879

Witmer, F.D.W., O'Loughlin, J., 2011. Detecting the effects of wars in the Caucasus regions of Russia and Georgia using radiometrically normalized DMSP-OLS nighttime lights imagery. GIScience Remote Sens. 48, 478-500. doi:10.2747/1548-1603.48.4.478

Yin, H., Prishchepov, A. V., Kuemmerle, T., Bleyhl, B., Buchner, J., Radeloff, V.C., 2018. Mapping agricultural land abandonment from spatial and temporal segmentation of Landsat time series. Remote Sens. Environ. 210, 12-24. doi:10.1016/j.rse.2018.02.050

Zabyelina, Y.G., 2013. 'Buying Peace' in Chechnya: Challenges of post-conflict reconstruction in the public sector. J. Peacebuilding Dev. 8, 37-49. doi:10.1080/15423166.2013.860343

Zürcher, C., 2007. The post-Soviet wars: Rebellion, ethnic conflict, and nationhood in the Caucasus. New York University Press. 